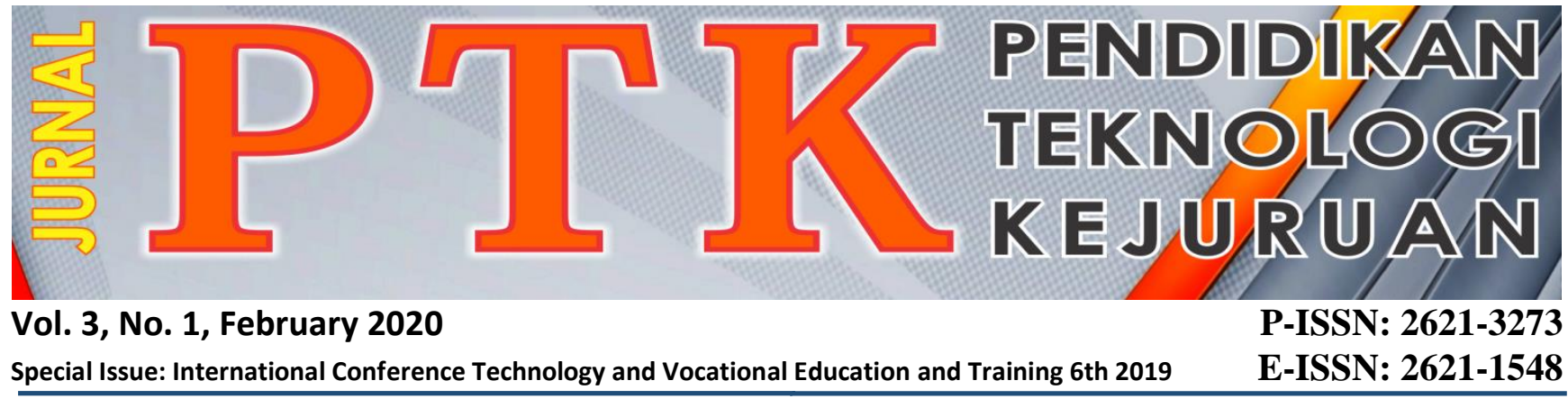

\title{
NEED ANALYSIS FOR THE DEVELOPMENT OF KOLB AND 4C INTEGRATION LEARNING MODEL-BASEL LESSON PLAN IN PEDAGOGY COURSE
}

\author{
Isnawati and Nizwardi Jalinus \\ 1Postgraduate of the Technology and Vocational Education, Universitas Negeri Padang, Padang \\ ${ }^{2}$ Mechanical Engineering, Faculty of Engineering, Universitas Negeri Padang \\ ${ }^{*}$ Corresponding author, e-mail: isnawati973@gmail .com ${ }^{1}$
}

\begin{abstract}
This study aims to: 1) Analyze the learning process to obtain information on the needs of lecturers and students as well as expectations in learning pedagogy, 2) analyze the learning styles of students by knowing each learning style of each student, 3) Analysis the learning models such as what was developed that can teach students according to the learning styles of each student. The research method used was a survey method. The data were collected by using questionnaires, interviews and observations. The results of this research obtained the level of mastery of the current pedagogical competence of students and the type of learning style of each student that illustrated the characteristics of their learning style. Then, the model used in the development of learning planning was the learning model of learning that can learn students according to the learning style of students so as creating the activeness of students in learning, critical thinking, creative, communicative and collaborative.
\end{abstract}

Keywords: Need Analysis, Planning Development, Pedagogy, Kolb learning and 4C

Copyright () 2020 JPTK. All rights reserved

\section{INTRODUCTION}

Experiential learning is a learning theory that makes experience a central role in the learning process where in the learning process and experience education becomes a very important source in each individual. Experiential learning from Kolb can provide opportunities for students to carry out an active learning process. Kolb learning model of learning makes individuals learn by using their own learning styles to develop the potential and skills in receiving subject matter [1]. Kolb Learning states the learning steps in experiential learning theory consist of four cycles, including: concrete experience stage (doing something), reflective observation stage (thinking about what has been done), abstract conceptualization stage (adding theory to the experience done), and active experimentation stage (putting into practice what has been learned) [2]. Kolb Learning model emphasizes the need for experience in the learning process, the activeness of a person in the learning process and the formation of intelligence that results from one's interaction with the environment [3]. Based on the four cycles proposed by Kolb, it can be described in the form of a circle in Figure 1:

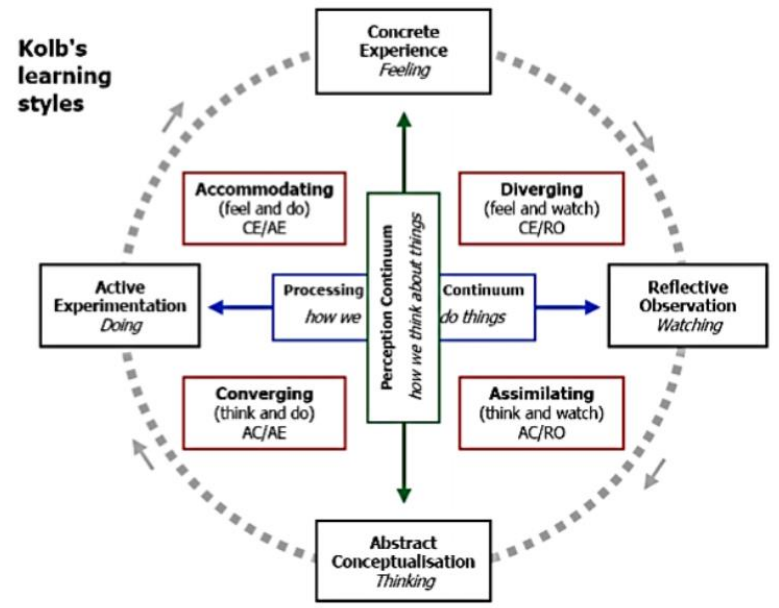

Figure 1. Kolb's Learning Style

Figure 1 explains the four positions of learning styles in the learning process. Each individual tends to have four learning styles: concrete experience is a learning style position of each individual learning through concrete experiences that directly find information by imaginative and innovative ways of 
learning characterized by students learning through feelings that are focused in terms of concrete experiences, relationships with others and sensitivity to the feelings of others, abstract conceptualization is the position of learning styles of each individual learning through reflective observation by observing information, then reflecting on that information and observing various problems from the viewpoint of students learning through observation, and observing before concluding a problem from various points of view, reflective observation is the position of learning style of each individual learning through abstract conceptualization by processing every information that is observed through theoretical and logical thinking that is marked by the students. Learning through thinking that is focused on logical analysis of ideas, systematic planning and intellectual understanding of each situation encountered, and active experimentation is the learning style of each individual learning through active experimentation by using theory to solve practical problems marked by student learning through action, carrying out tasks, dare to take risks and be able to influence others through their actions [4].

Kolb's experiential learning model makes students the center of learning in the learning process. [5] Kolb's learning model provides an opportunity for students to recognize their own learning styles. [6] Kolb's learning model is a learning method that takes into account the characteristics of the learning styles of each individual. [7] In the learning process each individual is not only dominated by one learning style, usually there is a combination of two poles in forming a learning orientation [8]. Based the four poles of learning styles described, it will form four combinations of learning styles. The concept to explore Kolb's learning styles and 21st century 4C learning skills can be illustrated in Figure 2 .

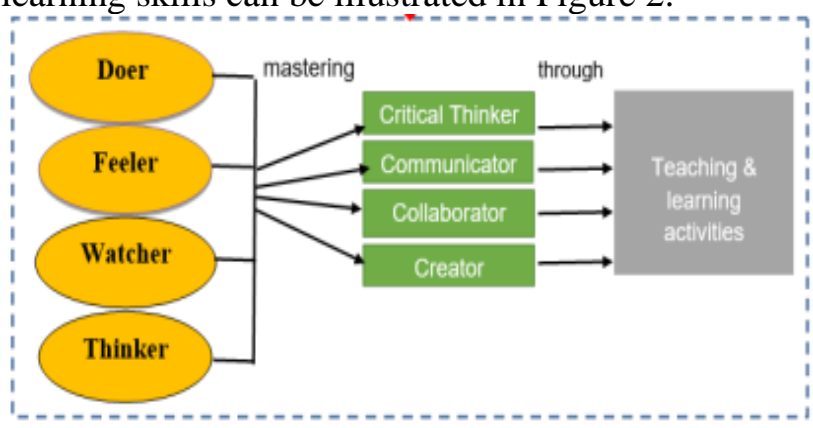

Figure 2. Combination of Kolb's Learning Style

Figure 2 explains the four combinations of Kolb's learning style positions that include: Doer is a combination of feel and do that applies a learning style by experiencing oneself concretely then putting into practice what has been learned. Feeler is a combination of think and do that applies learning styles through abstract conceptualization and then practices what has been learned. Thinker is a combination of Think and Watch that applies learning styles through abstract conceptualization. Then, individuals think about what has been done. Meanwhile, the watcher is a combination of feel and watch applying the learning style by living oneself concretely then the individual thinks about what has been done. Based on the four combinations of Kolb's learning model is predicted to master the four skills of the 21st century: critical thinkers, communicators, collaborators and creators produced through teaching and learning activities.

Kolb's experiential learning model is a part of a chair where students reflect on what they have learned so that they can actively fight in the learning process [9]. This is in line with the objectives of the pedagogy subject where students must be able to understand learners' learning styles, plan active learning processes that are capable of involving students in the learning process.

Based on observations made to PPG students of the Faculty of Engineering, Universitas Negeri Padang on 12 to 16 August 2019, there are several issues regarding the pedagogy competence of PPG students as follows: First, PPG students have not taught students according to the learning characteristics of the students, so they have not been able to develop the various potentials possessed. Second, the quality of PPG students in understanding learning models in implementing the teaching process of vocational education is less mastering. This has an impact on students' motivation in learning. The three PPG students have not yet carried out the learning process according to the students' learning styles, so they have not grown enthusiastic in participating in the learning process. Fourth, it is not in accordance with the learning styles of students, the lack of training of students in creative thinking, innovative in learning so that students face difficulties in completing the given task. The fifth, it is not yet involved ICTs in implementing the learning process that is in line with the demands of 21 st century learning so that graduates' achievements do not yet match the world of work. The six learning resources have not described the characteristics of the learning styles of students. In carrying out this observation researchers used a questionnaire used as a measurement tool to collect data. The questionnaire was distributed to PPG students of the Faculty of Engineering to measure pedagogical competencies of each PPG student.

This is in line with the education observer and Lecturer at Paramadina University, Mohammad Abduhzen that teacher pedagogy competency is still 
low. [10] Furthermore, based on the 2018 UKG results, the Director General of Teachers and Education Personnel (GTK) of the Ministry of Education and Culture explained that the average UKG results national concerns are still alarming based on UKG results the national average achievement of 53.02 is under the minimum competency standard (SKM) which is set at 55 .

Based on the background that has been described, it is necessary to follow up on the situation as a preliminary study in developing instructional design based on Kolb's learning models in pedagogy courses. The initial study of instructional design of the Kolb's learning model is very important in determining the learning styles of each student.

\section{METHODOLOGY}

The research method used was a survey method. The data were collected by using questionnaires containing questions related to pedagogical competence of PPG Vocational teachers and questionnaires about the student learning styles. The research was conducted at the Faculty of Engineering, Universitas Negeri Padang, in Electrical Engineering Education, Informatics Engineering Education, and Mechanical Engineering Education Departments. The sample studied was 47 respondents. Table 1 was a questionnaire to analyze the pedagogical competencies of PPG SMK teachers.

Table 1. The Pedagogical competency questionnaire PPG Vocational Teachers

\begin{tabular}{|l|l|l|}
\hline No & \multicolumn{1}{|c|}{ Indicators } & \multicolumn{1}{|c|}{$\begin{array}{c}\text { Question } \\
\text { Items }\end{array}$} \\
\hline 1 & $\begin{array}{l}\text { The concept of vocational } \\
\text { education }\end{array}$ & $1,2,3,4$ \\
2 & The Characteristics of Students & $5,6,7,8$ \\
3 & Learning Management & $9,10,11,12,13$, \\
& & $14,15,16,17,18$ \\
4 & Media and Learning Resources & $19,20,21,22,23$ \\
& & $, 24,25,26,27$ \\
\hline
\end{tabular}

The data from the questionnaire obtained were then analyzed by using a Likert scale that can be seen in table 2.

Table 2. Indicators of Likert scale variables.

\begin{tabular}{|c|c|}
\hline Variable Indicators & Scores \\
\hline Very mastered & 5 \\
Well mastered & 4 \\
Quite mastered & 3 \\
Less mastered & 2 \\
Not mastered & 1 \\
\hline
\end{tabular}

Then, the final scores were calculated by analyzing using the formula in equation 1.
$N A=\frac{S}{S M} \times 100 \%$

(Source: Riduwan 2010: 98)

Information:

NA $=$ Final Scores

$\mathrm{S} \quad=$ Score obtained

SM = Maximum Score

Based on the final scores obtained, then it can be categorized according to the level of achievement, as in table 3 .

Table 3. The Mastery Category

\begin{tabular}{|c|c|c|}
\hline No & $\begin{array}{c}\text { Achievement Levels } \\
(\%)\end{array}$ & Category \\
\hline 1 & $90-100$ & Very mastered \\
2 & $80-89$ & Well mastered \\
3 & $67-79$ & Quite mastered \\
4 & $55-64$ & Less mastered \\
5 & $0-54$ & Not mastered \\
\hline
\end{tabular}

Then, doing an analysis of the student learning styles. The data from the analysis of student learning styles were obtained from the filling of student learning style questionnaires. The determination of the learning styles of each student can be seen in Table 4.

Table 4. The Indicators of student learning styles

\begin{tabular}{|c|c|c|c|c|}
\hline Section & Variable Indicators & Yes & No & Sum \\
\hline 1 & Active Experimentation & & & \\
\hline 2 & $\begin{array}{l}\text { Reflective Observation } \\
\text { Abstract Conceptualization } \\
\text { Concrete Experience }\end{array}$ & & & \\
\hline
\end{tabular}

High scores from the two sections above were used to determine the learning style of each student.

Table 5. The Criteria for determining student learning styles

\begin{tabular}{|l|l|c|}
\hline No & \multicolumn{1}{|c|}{ Learning styles } & Learning Types \\
\hline 1 & $\begin{array}{l}\text { Concrete Experience and } \\
\text { Active Experimentation } \\
\text { Reflective Observation and } \\
\text { Concrete Experience }\end{array}$ & Doer \\
3 & $\begin{array}{l}\text { Abstract Conceptualization and } \\
\text { Reflective Observation } \\
\text { Abstract Conceptualization and } \\
\text { Active Experimentation }\end{array}$ & Thinker \\
\hline
\end{tabular}




\section{RESULTS AND DISCUSSION}

This needs analysis stage was carried out so that the lesson plan based on the developed Kolb learning model was able to assist teachers in teaching the students in accordance with the characteristics of the learning styles of students, and it could solve the obstacles faced by the students in critical thinking, creative and innovative in the learning process that if the learning process was carried out in accordance with the learning styles of students.

\section{A. Conducting interviews and distributing questionnaires}

Interviews and questionnaires were conducted to see the learning process carried out so far and to obtain data in the form of information about the needs of lecturers and the students as well as expectations in learning pedagogy. The distribution of questionnaires in the form of a questionnaire used was tested for the validity and reliability of the questionnaire. The sample of this stage of the research was the PPG students in the Electrical Engineering Education Study Program and Informatics Engineering Education Faculty of Engineering Department, Universitas Negeri Padang in the 2019/2020 academic consisting of 30 students. The indicators of the questionnaire instruments were: 1) mastery of the concept of vocational education 2) mastery of students' characteristics 3) mastery of learning planning and 4) mastery of media and learninig resources. Figure 3. showed the acquisition of pedagogical competency level mastery of PPG Vocational students viewed from each indicator.

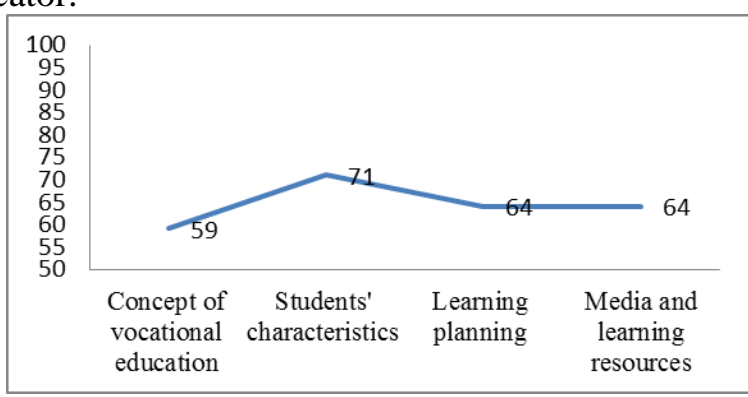

Figure 3.Pedagogical competency level mastery of PPG Vocational students

Based on the analysis of data on mastery of pedagogical competencies PPG students in positions consisting of 4 indicators indicated that:

1. The level of mastery of the concept of vocational education competency was 59\%, categorized as less mastered.

2. The level of mastery of the characteristics of students was $71 \%$ categorized quite mastered.

3. Learning Management Level was $64 \%$ categorized as less mastered.
4. The level of media mastery and learning resources was $64 \%$ categorized as less mastered.

The description of PPG students' pedagogical competencies was currently in the category of not mastered. There was only one indicator in the category of quite mastered. Then, the results showed that there were several pedagogical competencies in the low category.

\section{B. The Analysis of Student Learning Style}

The analysis of student learning styles was carried out to find out each learning style of each student. At this stage the researcher distributed learning style questionnaires to the students with four types of learning styles, and the students will fill in the types of learning styles that described the characteristics of their learning styles. In mechanical engineering education consisting of 47 respondents there were four types of student learning styles, as shown in Figure 4.

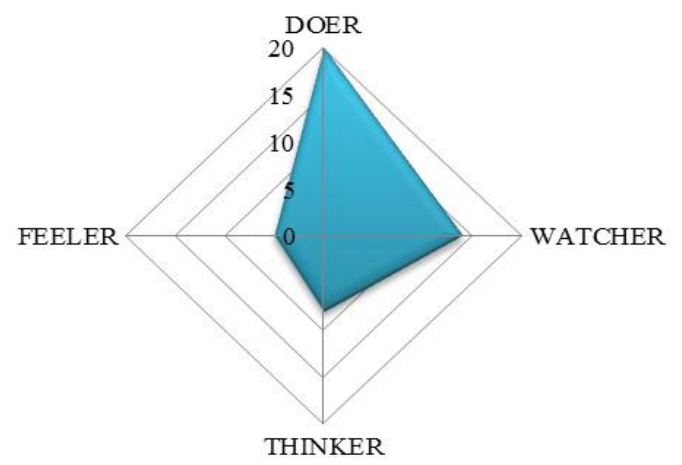

Figure 4. The Student learning style category

Figure 4. explained that there were 4 types of student learning styles of students in mechanical engineering, the type of learning style Doer was 20 students. 2) the type of learning style feeler was 5 students. 3) the type of learning style thinker 8 students and 4) the type of learning style watcher was 14 students.

\section{Analyze the learning model that will be used}

At this stage an analysis of the learning model was used. The learning model used must be able to make students have critical competence, creativity, collaboration and communication. The experiential learning model from Kolb teaches students according to the learning styles of students so as to provide opportunities for students to carry out active learning processes that make students directly involve in the learning process and construct their own learning experiences that are obtained and made into knowledge [11]. Kolb learning model of learning style is chosen and used by someone in 
increasing one's activity in the learning process [12]. Based on the description, the Kolb's learning model is needed that can teach students according to the learning styles of students so as to create the activeness of students in learning, critical thinking and meaningful.

\section{CONCLUSION}

The conclusions that can be drawn from the discussion above as follows: 1) Mastery of PPG teacher pedagogical competencies was still in the not mastered category 2) there are four types of learning styles for students in mechanical engineering education, a) 27 students have Doer learning style. b) 2 students have feeler learning style. c) 8 students has thinker learning style, and d) 10 students have watcher learning style. 2) The learning process carried out with the characteristics of the learning styles of students can overcome the obstacles experienced by students in critical thinking, creative and innovative in the learning process. 3) learning planning that is developed is an experiential learning model from Kolb that can teach students according to the learning styles of students so as to provide opportunities for students to carry out active learning processes that make students directly involve in the learning process and construct their own learning experiences obtained and made a knowledge.

\section{REFERENCES}

[1] Eishani Khalil Allah. et, al, The Relationship Between Learning Styles And Creativity. Journal of Social and Behavioral Sciences, 114 pp 52-55. 2014.

[2] Kolb, David A. Experiential Learning. New Jersey: Prentice Hall, Inc. Englewood Cliffs. 1984.

[3] Sugianto, Pengaruh Gaya Belajar experiential Learning dalam peningkatan Prestasi akademik Dan Penerapannya Dalam pembelajaran. paradigma Vol VIII No 15, pp 42-64. 2013.

[4] Silberman, Mel. Handbook Experiential Learning. Bandung : Nusa Media. 2016.

[5] Sudria, Ida Bagus Nyoman, dkk, Effect Of Kolb's Learning Styles Under Inductive Guided-Inquiry Learning On Learning Outcomes". International Journal of Instruction, Vol 11 No 1, pp 89-102. 2018.

[6] Sholihah, Mar'tus, dkk, Pengaruh Experiential Learning Model Kolb Learning Terhadap Kemampuan Berpikir Siswa. Jurnal Pendidikan Teori, Penelitian dan Pengembangan, Vol 1 No. 11, pp 2096-2100. 2016.
[7] Barida, Muda, Model Experiential Learning dalam Pembelajaran untuk Meningkatkan Keaktifan Bertanya Mahasiswa. Jurnal Fokus Konseling, Vol 4 No.2, pp 153-161. 2018.

[8] Kolb, A David and Alice Y. Kolb. The Kolb Learning Style Inventori 4.0: Guide to Theory, Psychometrics Research \& Applications, Experience Based Learning Systems, Inc. 2016.

[9] Lang, Hellmut R \& David N. Evans. Models, Strategi, and Method. For Effective Teaching. USA. Pearson Education, Inc. 2006.

[10] Destiani, Bosnita dan Pipit Utami, Urgensi Kompetensi Pedagogik Guru Vokasional Pada Pembelajaran Abad 21. Journal Electronics, Informatics, and Vocational Education, Vol 2 No 2, pp 211-222. 2017.

[11] Supiyanto, Yudi dan Dumiyati, Pengembangan Model Pembelajaran Microteaching Berbasis Experiential Learning Untuk Meningkatkan Keterampilan Mengajar". Jurnal Pengembangan Luaran Penelitian dan Pengabdian kepada Masyarakat Menuju Hak Kekayaan Intelektual (HKI) untuk Peningkatan Daya Saing Mendukung Kemandirian Bangsa, Vol 2, pp 13-20. 2017.

[12] Azrai, Eka Putri, dkk, The Influence of David Kolb's Learning Style (Diverger, Assimilator, Converger,Accommodator) to Students Learning Outcomes in Environmental Pollution, journal pendidikan biologi (BIOSFERJPB), Vol 10 No 1, pp 9-16. 2017.

[13] S. Syahril, N. Jalinus, R. A. Nabawi, and Y. Arbi, "The Create Skills of Vocational Students to Design a Product: Comparison Project Based Learning Versus Cooperative Learning-Project Based Learning," Adv. Soc. Sci. Educ. Humanit. Res., vol. 299, no. 5th UPI International Conference on Technical and Vocational Education and Training (ICTVET 2018) The, pp. 316-320, 2019. 